\title{
The Daimon in Hellenistic Astrology
}

by

Levente László

Budapest University of Technology and Economics

levente.laszlo@filozofia.bme.hu 


\title{
Abstract
}

A discussion of Dorian Greenbaum's The Daimon in Hellenistic Astrology: Origins and Influence.

\begin{abstract}
About the Author
LEVENTE LÁSZLÓ, MA in Latin (1977), is currently a PhD student in the Doctoral School of Philosophy at Eötvös Loránd University in Budapest, Hungary, as well as a team member of the Astra Project (hosted by CIUHCT, Portugal). His area of research is Hellenistic and Byzantine astrological literature, especially the questions of authorship, technical development, and transmission.
\end{abstract}




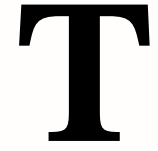

he word « $\delta \alpha i \mu \omega v »$ appears in the technical language of Hellenistic astrology in two contexts. On the one hand, two of the 12 topical places ( $\tau$ ó $\tau \mathrm{o})$ ), houses in modern astrological parlance, of the horoscope bear the traditional names "Good Daimon" and "Bad Daimon"; on the other, there is a calculated horoscopic point of the genre called lots ( $\kappa \lambda \hat{n}$ pot: parts) that is labeled the "Lot of Daimon". In both cases, this daimon is paired with fortune ( $\tau$ xq $)$.

Daimons are, of course, far more familiar from Greek mythology, theology, philosophy, and magic, especially in the form of a personal daimon, a supernatural entity acting as a guardian of an individual. These entities, it seems, often influenced astrology in its stricter or broader, more or less technical form when it was used to classify or describe daimons in order to communicate with them effectively or to find the personal daimon in an individual's nativity (birth-horoscope).

Furthermore, since daimons had a strong relationship with fate and destiny both in and outside technical astrology, and since astrology as a craft was meant primarily to be a study of fate, daimons and astrology were intertwined in antiquity in many ways. By singling out this relationship for the subject of her PhD thesis in the 2000s, Dorian Greenbaum found a promising area of research. The book under discussion here, The Daimon in Hellenistic Astrology: Origins and Influence [Greenbaum 2016], is an expanded and updated version of her dissertation of 2009.

The title itself of the book is somewhat misleading since it discusses not the daimon in Hellenistic astrology so much as the daimon and its intricate relationship with astrology; and the complexity of this subject is also reflected in the organization of the book. It is divided into three parts:

(1) Daimon and Fortune,

(2) Gods and Daimons, and

(3) Lots and the Daimon.

This structure might seem arbitrary but it is one of very few meaningful layouts that can organize the book's abundant sources and secondary literature. It also shows that the role of the daimon in astrology cannot be properly understood without the knowledge of the rich and complex cultural background in which astrology is embedded. 
In the first part ("Daimon and Fortune"), chapter 1 surveys the themes of the daimon, fortune, and astrology through the lenses of two representative authors of the second century AD, Plutarch and the astrologer Vettius Valens. The investigation of the latter is easily justified by the fact that Valens is practically the only known astrological author who has anything to say about the issues of fortune and fate beyond technicalities. Besides the various treatises from Plutarch's Moralia, the spurious De fato from the same era is surveyed to provide a full image of contemporary thinking about the daimon, fortune, and fate.

Chapter 2 is devoted to the astrological pairing of "Good Daimon" and "Good Fortune", that is, the names of the 11th and fifth places of a horoscope, respectively. It offers an analysis of astrological works from Manilius (early first century AD) to Rhetorius (fifth or early sixth century), who is considered the latest representative of Hellenistic astrology. This discussion is introduced with an eye to the wider historical and cultural background, using Greek and Demotic sources. This theme is continued into chapter 3, which investigates the issues raised in the previous chapter in the other Mediterranean cultures, most importantly, in Egypt and Mesopotamia. A convincing and highly important conclusion is found at the end of this chapter [114]: Greenbaum raises the possibility that the Greek concept of immutable fate was mitigated in Hellenistic astrology by oriental influences that allowed negotiation about fate.

The first part concludes with chapter 4, which treats the "Bad Daimon" and "Bad Fortune" (the names of the 12th and sixth places in Hellenistic astrology) in much the same way as their positive counterparts earlier. In this instance, however, Greenbaum summarizes briefly Mesopotamian, Egyptian, Greek, Jewish, and Christian traditions regarding demons (that is, malevolent daimons) before discussing astrological ideas.

Comparison of chapters 2-3 with chapter 4 reveals similarities in the survey of astrological authors, though there are also some dissimilarities. Of the latter, the different descriptions of the cultural background are entirely justifiable, but chapter 4 includes a table of names and descriptions of the sixth and 12th places [143-145] which chapter 2 oddly lacks. Although this table is useful as an overview of the ideas, in practice it suffers from two shortcomings. First, a table exhibiting the diachronic development of the themes related to these two topical places would have served the reader better than this potpourri of keywords collected from different astrological authors. Second, it seems that the known Hellenistic interpretation of the places is the result of the amalgamation of two cognate but different streams 


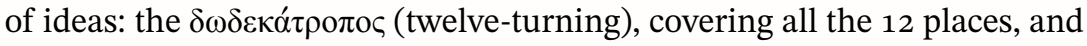

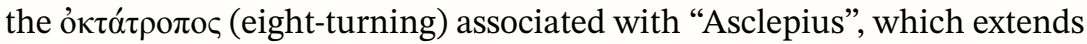
only over the first eight astrological places, including the fifth and the sixth,

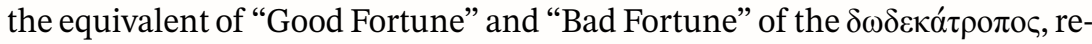
spectively [Beck 2007, 44-45]. These different constituents, although known by Greenbaum [400n5], are left unmentioned, though they should have been analyzed more carefully to give the necessary insight into the intricacies. The second part ("Gods and Daimons") consists of three chapters. In chapter 5, Greenbaum investigates Gnosticism and Mithraism to show how the role of daimons and their relation to gods are evaluated in harshly different ways within syncretic traditions in which astrological thinking is also found. At least two important achievements must be highlighted here: a new and

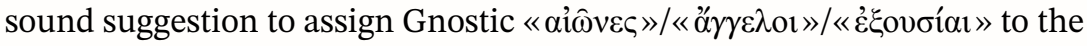
zodiacal signs and planets [174-175] as well as an intriguing treatment of the so far neglected thema dei found in the Byzantine summary of the Introductio of Antiochus of Athens [187-193]. This latter gives further support to Roger Beck's hypothesis that this Antiochus is identical with C. Iulius Antiochus Epiphanes Philopappus, the eponymous archon of Athens in the late first century AD. He belonged to the family of the astrologers Thrasyllus and Balbillus, whose activities, and therefore Antiochus', may well be connected to the rise of the Roman mysteries of Mithras [Beck 2006, 253-254].

Chapter 6 extends this inquiry of good and evil daimons into the realm of magical papyri, the philosophical Hermetica, and the decan-lore originating from Egypt and eventually subsumed into astrology. Here, some astrological works are examined along the same lines taken in the first part. Overall, the content of chapter 6 is rather vague.

In contrast, chapter 7 investigates the role of the personal daimon in Neoplatonism with a special focus on Porphyry, who links the idea of a personal

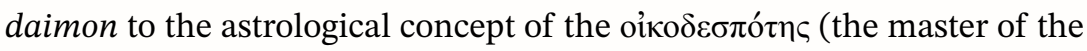
house), a type of a ruling planet in a nativity. This concept is not without

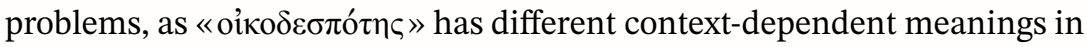
astrological texts; but these concerns are excellently clarified here [256-257]. More problematic is Greenbaum's acceptance of the Introductio ad Ptolemaei tetrabiblum, specifically its mostly uncontested chapters, as a genuine text of Porphyry. This issue and the analysis of "Porphyry's" (in fact, Anti-

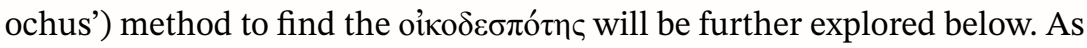
a final remark on this chapter, it is not clear how Greenbaum would like the reader to understand Iamblichus' five elements ( $\sigma \tau$ o $\chi \varepsilon i \hat{\alpha})$ in finding the 
оíкобвблótnc [256]: she refers to Ptolemy's technique as an example of these "five steps", but the exact meaning remains uncertain.

The final part ("Lots and the Daimon") is devoted to the previously mentioned astrological lots, chiefly to the Lot of Daimon, its counterpart, the Lot of Fortune, and further lots derived from them, as well as to their cultural background. Both these lots are calculated by measuring the interval between the Sun and the Moon from the Ascendant clockwise or counterclockwise, depending on whether the horoscope is cast in daytime or in nighttime. Chapter 8 explores the notion of lot in Hellenistic culture, emphasizing the connection between the daimon and lots in Plato's Myth of Er. This chapter concludes with a survey of the doctrine of lots in astrology, but the exploration of the rather extensive material is sensibly narrowed down to topics having greater importance, such as Manilius' idiosyncratic Circle of Athla (a sort of alternative $\delta \omega \delta \varepsilon \kappa \alpha ́ t \rho o \pi \circ$ c based on the position of the Lot of Fortune) and the lots found in the Panaretus, a lost book cited by the late fourth-century Paulus of Alexandria and attributed to Hermes. As is rightly pointed out, the names of these "Hermetic" lots (Fortune, Daimon, Necessity, Eros, Courage, Victory, and Nemesis) are all abstractions and have daemonic connotations [300]. Furthermore, the very important distinction between fatalism and determinism is raised here with the conclusion that Hellenistic astrologers in general, but at least Valens in particular, may have been determinists yet were definitely not fatalists [336].

Chapter 9 continues to investigate the two most important lots, those of Fortune and the Daimon, more closely, which makes this chapter perhaps the most technical in the book. Six carefully chosen case studies, mostly from Valens, illustrate the various usages of these lots as well as a derivative of theirs, the Lot of Basis. The chapter concludes with a section on the appearance of the two lots in the techniques of ascertaining the length of life. While the discussion is satisfactory in every detail, the usage of the Lot of Fortune in a katarchic context, for instance, in astrological thought-reading (see, e.g., Hephaestio, Apot. 3.4.14-18) might also have been mentioned.

Finally, chapter 10 adduces two more derivative lots (at least in a tradition separate from the Hermetic one), those of Love and Necessity. A section is devoted to the cultural background of the pairing of love and necessity and another one to their astrological role, supplemented with the assessment of all known horoscopes utilizing them, including a recently published horoscope on papyrus, P. Berlin 9825 [Greenbaum and Jones 2017], which, unlike the others, uses the Hermetic formulas. One notable achievement 
must be mentioned here: the association of the caduceus with the four lots, Fortune, Daimon, Eros, and Necessity.

The book ends with conclusions and several appendices, the first of which is a highly useful summary of astrological theory. The rest is mostly a collection of source-texts illustrating the various chapters. Conclusions also provide the reader with an excellent aid to discover the most important themes and threads of the book, which are often buried under the vast material.

What is deeply missed, however, is a chapter on methodology, even if it can be gleaned from the structure of the book that the aim is to read and utilize every piece of source material and scholarly literature related to the broader relationship of astrology and the daimon. Still, this barely conscious methodological approach results in a curious contrast between Greenbaum's handling of secondary literature and primary sources on astrology; while arguably all the accessible scholarly contributions are covered (the bibliography runs to 28 pages), the usage of the sources is rather haphazard.

In some cases, it is a mixed result of an uncritical acceptance of the accessible editions and ignorance of their recent re-evaluations. To give an example: texts from Antiochus' Thesauri (not Thesaurus, as referenced throughout the book) as edited by Franz Boll [1908] are cited six times, although David Pingree, in an article known and even cited four times by Greenbaum, warned that this attribution is largely mistaken [1977, 214-215].

Another problem of minor importance is that Greenbaum appears completely unaware of the syncretic tendency of astrological text-editions prior to the publication of the first volume of Hephaestio of Thebes by Pingree [1973]. Before that year, editors, in an attempt to reconstruct a hypothesized common ancestor of manuscripts, eliminated the boundaries between different recensions, re-workings, epitomes, and excerpts in order to create an idealized but in fact conflated text that had never existed yet might please the aesthetics of similarly inclined classical philologists. This discomforting fact was first emphasized by Pingree [1977, 203], and has been repeated and aptly illustrated by Stephan Heilen recently [2010, 301-303]. Certainly, no readers or reviewers ought to expect Greenbaum to reconstruct, for instance, the different versions behind Emilie Boer's edition of Paulus [1958] from scratch. But the fact that not even allusions are made to the existence of available parallel texts, as in the case of Hephaestio, is rather alarming. Fortunately, the interpretations of the passages are rarely affected by this deficiency. Compared to these two issues, the third problem is by far more general and pervasive in the book. While the theories expounded by different astrological 
authors are frequently discussed in various chapters, the development of ideas as it is displayed in the source-texts is scarcely elaborated. I shall illustrate this claim with a randomly chosen example: the relationship of the fifth astrological place and children, discussed in chapter 2 [50-76].

Here, Greenbaum, assessing Manilius' poem, is astounded by his association of health-issues with the fifth place, which is "unlike traditional descriptions of the fifth, which stress fertility and children" [60]. The significations given by Antiochus, "both the acquisition of living beings ( $\dot{\mu} \psi v \dot{\chi} \chi \omega \vee \kappa \tau \hat{\imath} \sigma \varsigma)$ and the increase of things pertaining to living" [65], are also received reluctantly. On the other hand, she concedes that many other astrologers associate children with this place.

Had she compared the texts giving descriptions both of the aforementioned

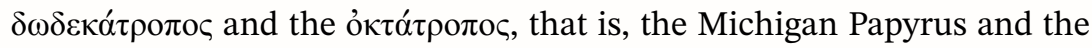
works of Thrasyllus, Antiochus, and Firmicus Maternus, more carefully, she should have noticed that (except in the description of Firmicus Maternus, who is two or three centuries later than the other authors) while the

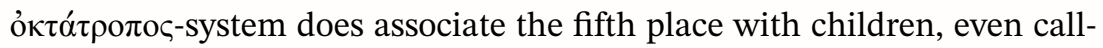

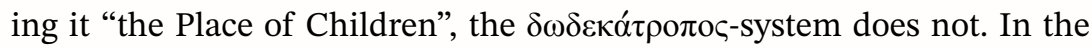
latter system, the fifth place either means some unqualified good fortune or is further elaborated in various ways by Manilius, Antiochus, and Valens [67]. Although one may argue that children can be interpreted as part of the broader context of Good Fortune (and, incidentally, also of the Good Daimon) in the $\delta \omega \delta \varepsilon \kappa \alpha ́ \tau \rho о \pi о \varsigma$, the interpretations of the planets lingering in the fifth place given by Valens [67] and Firmicus Maternus [70] have only to do with overall fortune and success, not with children.

Admittedly, there exists another tradition that does interpret planets in the fifth place as conveying indications exclusively for children, a tradition found in the works of Paulus and, of course, Olympiodorus [74], as well as in a poem cited in "Palchus" 134 as attributed, probably falsely, to Antiochus [Pérez Jiménez 2011]. ${ }^{1}$ Also, the amalgamation of the indications of the fifth

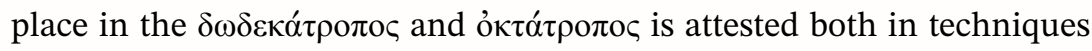
related to the genethlialogical topic of children and in a description by Valens [Anth. 4.12.1], overlooked by Greenbaum, which calls the fifth place that "of children, friendship, partnership, slaves, freedmen, acquisition, ${ }^{2}$

${ }^{1}$ Greenbaum does not mention Pérez Jiménez 2011.

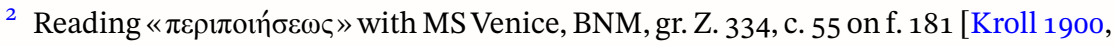

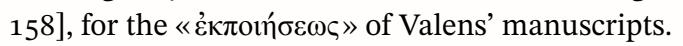


some good deed or good service"-covering also many of the meanings of the 11 th place.

This example illustrates how complex the development and transmission of astrological ideas was, and the significance of Greenbaum's failure to separate the distinct but interrelated threads. Her undeclared method of aggregating sources-which are sometimes barely reliable, and at other times attributed to certain authors without solid ground-with occasional oversight of relevant texts seems to have resulted in these three problems in her account. Greenbaum also falls into the trap of building narratives, one being exceptionally grand and fragile: Porphyry's paramount role as a link between fate, the Platonic daimon, and astrology. Whereas Porphyry's importance in this context cannot really be denied, as was already mentioned, Greenbaum throws caution to the winds when she accepts the text entitled «Порфvpíov $\varphi$ १ı "Introductio ad Ptolemaei tetrabiblum") as genuinely his. In truth, several arguments may be raised against his authorship beyond the ones mentioned [266-267n122; László 2021]. Most of the Introductio attributed to Porphyry is a slightly adapted copy of Antiochus' Introductio, which is seen in chapter 30, the very one analyzed and discussed by Greenbaum [268-273]. The investigation of the кúpıc is postponed [Boer and Weinstock 1940, 207.28]; but this promise will be fulfilled only in Antiochus, Epit. intro. 2.3 [Cumont 1912, 119.22-33], the original of which is now lost. Therefore, this chapter, which for Greenbaum is the key text linking Porphyry's ideas of the personal daimon to astrological technicalities, is probably Antiochus' genuine text, otherwise summarized in Epit. intro. 1.28 [Cumont 1912, 118.9-22].

A final remark about Antiochus. The two major works associated with his name are the Thesauri and the Introductio. The Thesauri is extant in its fullest form as book 5 of Rhetorius, Comp. [Pingree 1977, 210-212]; whereas the Introductio is lost, save for a summary in Epit. intro. [Cumont 1912, 111-119], several chapters in [Porphyry]'s Introductio, and a few fragments. Since several chapters of the Thesauri overlap with what is extant of the Introductio and are mostly reworked [Pingree 1977, 207-208], it is reasonable to assume that, since Antiochus alone was the author of the Introductio, his name was attached to the Thesauri only as a mistake by Rhetorius, and that the chapters in Rhetorius' Comp. resembling the ones in the Introductio are barely adaptations [cf. Schmidt 2009, 21]. Certainly, one cannot entirely dismiss the idea that certain chapters of the Thesauri missing from the summary of the Introductio may have been authored originally by Antiochus, 
while their present form is obviously due to Rhetorius. Therefore, it seems more reasonable to associate the Thesauri with Rhetorius, not Antiochus. ${ }^{3}$ In the following, I record some minor corrections, additions, and remarks:

(1) $8 \mathrm{n} 28 ; 27 \mathrm{n} 44 ; 306 \mathrm{n} 14 ; 309 \mathrm{n} 24 ; 310 \mathrm{n} 30 ; 447-449$ : CCAG 1.160 is not genuine Antiochus, but Rhetorius, Comp. 5.47 ultimately stemming back to Paulus (as is also acknowledged).

(2) $21 \mathrm{n} 16$ and $306 \mathrm{n} 14$ : CCAG 7.127 is Rhetorius, Epit. IIIb xvi; but it is in fact a copy of Antiochus, Epit. intro. 1.1 [Cumont 1912, 112.2-4 (Moon), 111.18-19 (Sun)].

(3) 50: the concept of Jupiter and Venus being the greater and lesser benefics, respectively, is medieval, postdating Guido Bonatti and Leopold of Austria (13th century), who do not mention it.

(4) 63-64; 279 and n4; 311: comparing Dorotheus, Carm. astrol. 1.24.6 to the available Latin translation of an Arabic version composed around 800 by al-Khayyāt [Heller 1549, d2v-d3], the word "fortune" (Arabic «sa'ādah» [Pingree 1976a, 30.5] ) most likely refers to material fortune, in the same manner as towards the end of the sentence [Pingree 1976a, 30.6].

(5) 65 n9o: CCAG I, 157 is Rhetorius, Comp. 5.28, using Antiochus, Epit. intro. 1.18 [Cumont 1912, 116.3-6], which is found in another version as [Porphyry], Intro. 36 [Boer and Weinstock 1940, 209.19-21]. This latter is quoted here.

(6) 143-145 and 149 n159: CCAG 7.114-115 is not Antiochus, but Rhetorius, Epit. IIIb 21, deriving from Rhetorius, Comp. 5.59, which is quoted here in 149 n159. Therefore, delete "dog-men" and "epileptics" on 143. The referenced passage in the Liber Hermetis (more correctly, De triginta sex decanis) originates from Rhetorius.

(7) 146 n148: read Rhetorius, Comp. 5.57 = Rhetorius, Epit. IV 1.

(8) 146 n150; 148 n155; 148 and n157; 149 n161: Rhetorius draws on Firmicus, Math. 3.4.34, 3.5.39, 3.6.25-26, and 3.4.11, respectively.

(9) 148 and n158: CCAG 7.114 is not Antiochus, but Rhetorius, Epit. IIIb 21, deriving from Rhetorius, Comp. 5.56.

(10) 167 and then passim: in fact, the expression "Chaldean order" is an early modern derivation from Macrobius, In somn. 1.19.2, and was never used as such by Hellenistic astrological authors, who favor the expression

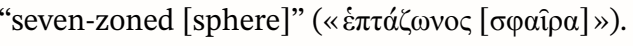

${ }^{3}$ For a recent evaluation of the texts associated with Rhetorius, see László 2020. In the present discussion, however, the results published there are not utilized. 
(11) 184 n115: Antiochus' authorship of the calendar, which is the second part of Rhetorius, Comp. $6.7=$ Rhetorius, Epit. IIIb x, is contested [Pingree 1977, 215]. CCAG 1.163 is Rhetorius, Comp. 5.51. Whether it is from Antiochus is uncertain.

(12) 186 n119: Paulus, Intro. 37 is a late addition since it is omitted from the extant summary [Cumont 1912, 95-97; Boer 1958, xxi-xxiv], and not contained in several manuscripts. Its alternative thema mundi is probably translated or adapted from Arabic.

(13) 227 nn147-148 and 229 n157: the so-called "scholium 9" of Paulus is not a scholium but an addition to Paulus, Intro. 4 in branch $\beta$ of Paulus' manuscripts [Boer 1958, xii] from Rhetorius, Comp. 5.10, which latter is also copied into [Porphyry], Intro. 47. It is probably not from Antiochus.

(14) 232 n168: "Liber Hermetis" in fact descends from the quoted Rhetorius

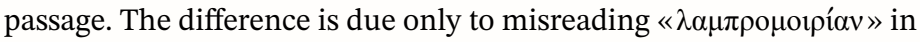

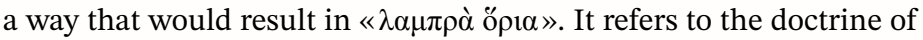
"bright degrees", which has different traditions. Rhetorius, Comp. 6.17 tabulates one, which will be later transmitted into Arabic astrology, while De trig. sex. dec.3.1-16 describes a different system. There are many further variants [cf. Heilen 2015, 2.1320-1323].

(15) $257 \mathrm{n} 87$ and 436-437: under "Palchus", the anonymous astrologer of the emperor Zeno must be understood. For No. L486 [436] see now Pingree's edition [1976b, 148-149]; No. L487 [437] appears, among others, as "Palchus" 87 , and there is one more horoscope, dated to 479 , also in

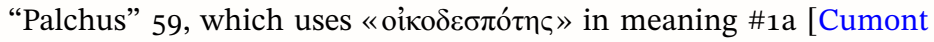
1898, 104.15]. This latter is omitted from the TLG.

(16) 311 and n32: CCAG 1.161 is not Antiochus, but Rhetorius, Comp. 5.48.

(17) 311 and n33: CCAG 7.113 is not Antiochus, but Rhetorius, Epit. IIIb 20, deriving from Rhetorius, Comp. 5.65.

(18) 314 and n42: Antiochus, Epit. intro. 1.4 [Cumont 1912, 113.8-9], which is apparently a concise summary of [Porphyry], Intro. 44, does not use the Lots of Fortune and the Daimon in the zodiacal melothesia; however, Rhetorius Comp. 5.14, copied as [Porphyry], Intro. 50, does, referring to Rhetorius Comp. $5.61=$ Rhetorius, Epit. IV 4, which in parts is clearly based on Valens, Anth. 2.37 [Pingree 1977, 214]. The source of the doctrine, therefore, is Valens.

(19) 376 and 480: the horoscopic fragment is probably an insertion into Olympiodorus' text since it appears in the middle of lists of lots [Boer 1962, 53-59] already inserted into the hyparchetype of the extant manuscripts [Burnett and Pingree 1997, 191].

(20) 387 n179 and 475: Abū Ma'shar's Lots of Affection and Love (sahm al-ulfah wa-al-hubb) and of Poverty and Lack of Means (sahm al-faqr wa-qillat al-hayāh) (ninth century) together with the other lots were 
simply copied by al-Bīrūnī in the 11th century, only the English translations differ. The same is true in the case of his adaptation of the list of lots in his Kitāb al-mudkhal (al-kabìr) ([Great] Introduction), into the more concise treatise entitled "Mukhtașar al-mudkhal" (The Abbreviation of the Introduction), also known as the Kitāb al-mudkhal al-șaghīr (Little Introduction). The records for these works are badly confused in the index [551]. It must also be noted that John of Seville, a translator of the Great Introduction, interpreted the word «ḥayāh », meaning "life; faculty of growth, sensation or intellect”, in a Mercurial way to produce "ingenium" [Lemay 1995-1996, 6.332.439]; see also Adelard of Bath in his translation of the Mukhtașar writing "useless concern" (6.8: sollicitudo inefficax) [Burnett, Yamamoto and Yano 1994, 128]. These lots, however, had already been known in the eighth century by Māshāallāh: see Liber Aristotilis 3.xii.1.2 and 3.xii.3.3. The source is Dorotheus [Burnett and Pingree 1997, 194]; the history of lots is considerably more complicated than what Greenbaum's examination suggests.

(21) 399 n2: only the definition of the tropical zodiac is given here, although until about the fourth century astrologers used a certain type of sidereal zodiac exclusively [Jones 2010]. The reference to Antiochus should also be to Rhetorius, Comp. 5.proem.

(22) $400 \mathrm{n} 6$ : the description of the quadrant-system does not appear in the genuine text of Olympiodorus, only in the 14 th-century reworking composed probably by Isaac Argyrus [Caballero-Sánchez 2013, 94-98].

(23) 404: the expression "Ptolemaic aspects" is a double misnomer in the Hellenistic astrological context. On the one hand, there seems to be no dedicated expression for "aspects" before Arabic astrology, save for words deriving from « $\sigma \chi \hat{\eta} \mu \alpha »$ and verbs involving the notion of vision. On the other, the "classical" configurations are first called "Ptolemaic aspects" only in the 17th century, after Kepler's "invention" of the socalled "minor aspects" [De fundamentis astrologiae certioribus, thesis 38: [Kepler 1601, c1v]]. In this latter context, it reflects the false but widespread assumption that Ptolemy was the archetypal Hellenistic astrologer.

(24) 408 n22: read Rhetorius 5.7 for Antiochus. For the genuine description of Antiochus, see Epit. intro. 1.3 [Cumont 1912, 112.27-28], whose original is perhaps [Porphyry], Intro. 6.

(25) 417-418: Emilie Boer's edition of Paulus [1958] is a conflation of different recensions of Paulus' text, and consequently its apparatus must be closely followed. There is no room to cite all the non-trivial testimonies here; it is sufficient, however, to remark that the version found in Rhetorius, Comp. 6.30 on ff. 191-196 of MS Paris, BNF, gr. 2425 (Boer's ms $Y$ ) and the closely related but radically reworked version in Rhetorius, Epit. IIIb (Boer's ms family $\delta$ [Boer 1958, xii; Pingree 1977, 212-215]) 


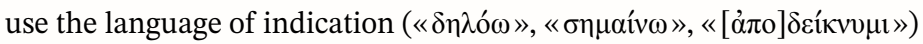
consistently, in contrast with the language of causation found in the other recensions whose readings are accepted in the edition.

(26) 429-431: for the new edition of Antigonus' examples, see Heilen's edition [2015]: for No. L40, see 1.160-161; for No. L76, see 1.130-131 and 133-137; for No. L113, IV, see 1.168-169 and 172-175.

(27) 433: Greenbaum's suggestion is an excellent and exemplary emendation of the defective text.

(28) 450-452: this is a part of Rhetorius, Comp. 5.54; cf. De sex. dec. 16.30-45 (seventh consideration) and 16.22 (fifth consideration), which originates in the same Rhetorius' text but provides the numerous emendations used here. Pingree's manuscript (also mentioned on xviii) is the above-mentioned Paris, BNF, gr. 2425, which provides books 5-6 of Rhetorius, Comp., including the summaries of Paulus and Antiochus' Introductio.

Apart from these deficiencies, mostly rooted in concerns about texts, there are many positive aspects of Greenbaum's approach. She understands Hellenistic astrology, including the perspective of a practitioner. She is sympathetic with features of astrology that are often blamed or ridiculed by others-for instance, the existence of myriads of techniques [301] —-solely on the ground of preconceptions and ignorance. This is a refreshing advance beyond the occasional presentist biases of other scholars. At the same time, she laudably avoids, at least in the majority of possible cases, the pitfall of anachronism in astrological techniques, which could lead to confusion. The excellent quality of English writing must also be highlighted.

In summary, Greenbaum's The Daimon in Hellenistic Astrology will indubitably enthrall those interested in the difference between fatalism and determinism and in the solutions provided by astrologers of the past. Moreover, it yields insight into the technicalities and practices of Hellenistic astrology.

\section{BIBLIOGRAPHY}

CCAG Catalogus codicum astrologorum Graecorum.

TLG Thesaurus Linguae Graecae (https://stephanus.tlg.uci.edu/).

Beck, R. 2006. The Religion of the Mithras Cult in the Roman Empire. New York.

2007. A Brief History of Ancient Astrology. Malden, MA.

Boer, E. 1958. Pauli Alexandrini elementa apotelesmatica. Leipzig. 
Boer, E. 1962. Heliodori ut dicitur in Paulum Alexandrinum commentarium. Leipzig.

Boer, E. and S. Weinstock. 1940. "Porphyrii philosophi introductio in tetrabiblum Ptolemaei”. CCAG 5.4: 187-228.

Boll, F. 1908. "Excerpta ex Antiochi thesauro et ex Heliodoro”. CCAG 7: 107-122.

Burnett, C. and D. Pingree. 1997. The Liber Aristotilis of Hugo of Santalla. London.

Burnett, C.; K. Yamamoto; and M. Yano. 1994. Abū Ma’šar: The Abbreviation of the Introduction to Astrology. Leiden.

Caballero-Sánchez, R. 2013. "Historia del texto del Comentario anónimo al Tetrabiblos de Tolomeo". MHNH 13: 77-198.

Cumont, F. 1898. "Palchi capitula selecta”. CCAG 1: 94-117.

1912. "Librorum astrologicorum epitome Parisina". CCAG 8.3: 91-119.

Greenbaum, D. G. 2016. The Daimon in Hellenistic Astrology: Origins and Influence. Leiden/Boston.

Greenbaum, D. G. and A. Jones. 2017. "P.Berl. 9825: An Elaborate Horoscope for $319 \mathrm{CE}$ and Its Significance for Greek Astronomical and Astrological Practice”. ISAW Papers 12. https://dlib.nyu.edu/awdl/ isaw/isaw-papers/12/.

Heilen, S. 2010. "Problems in Translating Ancient Greek Astrological Texts”. Pp. 299-329 in A. Imhausen and T. Pommerening edd. Writings of Early Scholars in the Ancient Near East, Egypt and Greece: Translating Ancient Scientific Texts. Berlin/New York.

_2015. "Hadriani genitura”. Die astrologischen Fragmente des Antigonos von Nikaia. 2 vols. Berlin/Boston.

Heller, J. 1549. Albohali Arabis astrologi antiquissimi, ac clarissimi de iudiciis natiuitatu[m] liber unus, antehac non editus. Nuremberg.

Jones, A. 2010. “Ancient Rejection and Adoption of Ptolemy's Frame of Reference for Longitudes". Pp. 11-44 in A. Jones ed. Ptolemy in Perspective: Use and Criticism of his Work from Antiquity to the Nineteenth Century. New York.

Kepler, J. 1601. De fundamentis astrologiae certioribus. Prague.

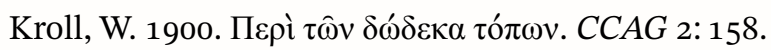

László, L. 2020. “Rhetorius, Zeno’s Astrologer, and a Sixth-Century Astrological Compendium”. Dumbarton Oaks Papers 74:329-350. 
László, L. 2021. "Revisiting the Authenticity of Porphyry's Introduction to Ptolemy's Apotelesmatics". Classical Philology (in press).

Lemay, R. 1995-1996. Albumasar. Liber introductorii maioris ad scientiam judiciorum astrorum. 9 vols. Naples.

Pérez Jiménez, A. 2011. "Poésie et astrologie chez Antiochos". Pp. 181-191 in I. Boehm and W. Hübner edd. La poésie astrologique dans l'Antiquité. Paris.

Pingree, D. 1971. "The Astrological School of John Abramius". Dumbarton Oaks Papers 25: 189-215.

_ 1973. Hephaestionis Thebani apotelesmaticorum libri tres. Leipzig.

1976a. Dorothei Sidonii carmen astrologicum. Leipzig.

_ 1976b. "Political Horoscopes from the Reign of Zeno". Dumbarton Oaks Papers 30: 133-150

_ 1977. "Antiochus and Rhetorius". Classical Philology 72: 203-223.

Schmidt, R. 2009. Antiochus, with Porphyry, Rhetorius, Serapio, Thrasyllus, Antigonus et al.: Definitions and Foundations. Cumberland, MD. 